\title{
Article \\ Removal of Cesium from Radioactive Waste Liquids Using Geomaterials
}

\author{
Haixin Zhang ${ }^{1}$, Mingze Zhu ${ }^{1}$, Xiaoyu Du ${ }^{1,2}$, Sihan Feng ${ }^{1,3}$, Naoto Miyamoto ${ }^{4}$ and Naoki Kano ${ }^{4, *}$ (D) \\ 1 Graduate School of Science and Technology, Niigata University, 8050 Ikarashi 2-Nocho, Nishi-ku, \\ Niigata 950-2181, Japan; F21K005K@mail.cc.niigata-u.ac.jp (H.Z.); F21K002E@mail.cc.niigata-u.ac.jp (M.Z.); \\ xiaoyudu90@163.com (X.D.); fengsihan0111@163.com (S.F.) \\ 2 Heilongjiang Provincial Key Laboratory of Surface Active Agent and Auxiliary, Qiqihar University, \\ Qiqihar 161006, China \\ 3 Daqing Petrochemical Research Center, 2 Chengxiang Road, Yixi, Longfeng District, Daqing 163311, China \\ 4 Department of Chemistry and Chemical Engineering, Faculty of Engineering, Niigata University, \\ 8050 Ikarashi 2-Nocho, Nishi-ku, Niigata 950-2181, Japan; nmiyamoto@eng.niigata-u.ac.jp \\ * Correspondence: kano@eng.niigata-u.ac.jp; Tel.: +81-025-262-7218
}

Citation: Zhang, H.; Zhu, M.; Du, X.; Feng, S.; Miyamoto, N.; Kano, N. Removal of Cesium from Radioactive Waste Liquids Using Geomaterials. Appl. Sci. 2021, 11, 8407. https:// doi.org/10.3390/app11188407

Academic Editor: Dibyendu Sarkar

Received: 16 August 2021

Accepted: 8 September 2021

Published: 10 September 2021

Publisher's Note: MDPI stays neutral with regard to jurisdictional claims in published maps and institutional affiliations.

Copyright: (c) 2021 by the authors. Licensee MDPI, Basel, Switzerland. This article is an open access article distributed under the terms and conditions of the Creative Commons Attribution (CC BY) license (https:// creativecommons.org/licenses/by/ $4.0 /)$.

\begin{abstract}
In this study, we investigated the removal of Cs from aqueous solutions using geomaterials. Adsorption was chosen as an effective method to develop for the removal of Cs from radioactive waste liquids. Geomaterials, including fly ash and slag as raw materials, were prepared as adsorbents using an alkali activator. The materials were characterized by X-ray diffraction (XRD); scanning electron microscopy with energy dispersive spectrometer (SEM-EDS); and BET surface area, pore volume, and pore size analysis. The effects of various parameters, such as $\mathrm{pH}$, contact time, and adsorbent dosage on the adsorption of the Cs were studied. The partition coefficient (PC) as well as the adsorption capacity were evaluated to assess the true performance of the adsorbent in this work. The fly ash-based geomaterials showed a maximum Cs adsorption capacity of $89.32 \mathrm{mg} \cdot \mathrm{g}^{-1}$ and a high PC of $31.02 \mathrm{mg} \cdot \mathrm{g}^{-1} \cdot \mathrm{mM}^{-1}$ for the Cs under our experimental conditions. From this work, this method can be regarded being practical for use as a potential adsorbent for treating Cs in wastewater. Furthermore, the immobilization of Cs in geomaterials was explored from a chemical perspective. In conclusion, fly ash-based geomaterials may be a promising option for the treatment and disposal of nuclear-contaminated waste.
\end{abstract}

Keywords: cesium (Cs); radioactive waste liquid; fly ash; geomaterials; adsorption capacity; partition coefficient

\section{Introduction}

With the development of modern science and technology, nuclear energy has been widely applied in industry, national defense, agriculture, medicine, and scientific research. However, radioactive waste liquid has been produced with the rapid development of the nuclear industry. For example, due to the Fukushima Daiichi nuclear power plant accident in Japan in 2011, a significant amount of radioactive material leaked, and a substantial volume of wastewater containing radioactive cesium (Cs) was discharged. As these waste liquids are radioactive and can cause immeasurable harm to the environment and human bodies. Among them, ${ }^{137} \mathrm{Cs}$ is the most common radionuclide in this type of waste liquid; it produces continuous radioactivity and biological toxicity and has a half-life of about 30 years [1,2]. ${ }^{137} \mathrm{C}$ s mainly releases $\beta$ and $\gamma$ rays, which are enriched in human muscles and expose the entire body to radiation. In addition, it may cause cell carcinogenesis, leading to long-term effects and genetic hazards, such as leukemia, infertility, and fetal malformations. The continued harm caused by the nuclear leakage accident at the Fukushima Daiichi Nuclear Power Plant once again sounds the alarm for humankind [3-6]. Due to this disaster, the removal of radioactive cesium as well as strontium in water has gained considerable attention from many scholars around the world. 
The current removal methods for radioactive cesium mainly include chemical precipitation [7-10], solvent extraction [11-14], membrane separation [15-18], biological treatment $[19,20]$, and adsorption [21-24]. The adsorption method is widely used in the removal of radionuclides in water due to its high efficiency, simplicity, high selectivity, and strong adaptability. In recent years, the most versatile inorganic materials that have been used to remove radioactive cesium in water mainly include geopolymers, nano-carbon materials, and metal oxides, among others [25-27].

Geomaterial [28] is a type of inorganic cementitious polymer material that has been developed in recent years. It uses calcined clay (metakaolin), volcanic pumice, fly ash, mineral waste slag, and other silico-alumina materials as raw materials. Under the action of the activator, a polymerization reaction occurs to form a three-dimensional, network-like, high-strength dense material that is mainly composed of silicon-oxygen tetrahedrons and aluminum-oxygen tetrahedrons and that has amorphous and quasi-crystalline characteristics.

With regard to the current problem of the solidification of heavy metal and radioactive waste, this study proposes a practical solution. For our experiments, we used synthetic fly ash-based geomaterials at room temperature, which can overcome some of the consequences of solidified heavy metal and nuclear waste, both locally and abroad. It has the advantages of a low solidification treatment cost, a simple and easy-to-control process, and it can reduce or avoid secondary pollution. This study provides a theoretical basis for the optimization and preparation of adsorption materials with high-efficiency adsorption performance and lays a foundation for the solidification of heavy metal and nuclear waste and their safe adsorption and disposal. It is of great significance to the healthy and sustainable development of the modern economy.

\section{Materials and Methods}

The main chemical components of ordinary Portland cement, fly ash, and slag are $\mathrm{CaO}$, $\mathrm{SiO}_{2}, \mathrm{Al}_{2} \mathrm{O}_{3}, \mathrm{Fe}_{2} \mathrm{O}_{3}, \mathrm{MgO}$, and $\mathrm{TiO}_{2}$. These chemical reagents were purchased from Kanto Chemical Co., Ltd. (Tokyo, Japan). The reagents $\mathrm{NaOH}$, sodium silicate, and $\mathrm{CsCl}$ were of analytical grade and were also purchased from Kanto Chemical Co., Ltd. (Tokyo, Japan). In addition, a BT100 Water Bath Incubator (Yamato Kagaku Co., Ltd., Tokyo, Japan), a DP33 Vacuum Drying Oven (Yamato Kagaku Co., Ltd., Tokyo, Japan), a pH meter (HORIBA F-72, Tokyo, Japan), an X-ray diffractometer (XRD, D2 Phaser, Bruker, Yokohama, Japan), a scanning electron microscope and an energy dispersive spectrometer (SEM-EDS, JEOL, Akishima City, Tokyo, Japan: JCM-6000 with JED-2300), and a specific surface area and pore size analyzer (N2-BET; TriStar 3020, Micromeritics, Norcross, GA, USA) were employed in this work.

\subsection{Synthesis of the Adsorbent}

$\mathrm{CaO}, \mathrm{SiO}_{2}, \mathrm{Al}_{2} \mathrm{O}_{3}, \mathrm{Fe}_{2} \mathrm{O}_{3}, \mathrm{MgO}$, and $\mathrm{TiO}_{2}$ were mixed in a certain weight ratio, listed in Table 1, to prepare ordinary Portland cement, fly ash, and slag. The fly ash and slag were used as geomaterials, and the Portland cement was used as a reference material.

Table 1. Chemical compositions of the raw materials.

\begin{tabular}{cccc}
\hline \multicolumn{4}{c}{ Weight of Mixture (g) } \\
\hline Chemical Compositions & Portland Cement & Fly Ash & Slag \\
\hline $\mathrm{CaO}$ & 15.6 & 2.65 & 23.9 \\
$\mathrm{SiO}$ & 5.25 & 25.8 & 16.2 \\
$\mathrm{Al}_{2} \mathrm{O}_{3}$ & 1.48 & 11.0 & 5.75 \\
$\mathrm{Fe}_{2} \mathrm{O}_{3}$ & 0.800 & 5.40 & 0.300 \\
$\mathrm{MgO}^{\mathrm{TiO}}$ & 0.700 & 1.00 & 1.50 \\
2 & - & 0.800 & 0.250 \\
\hline
\end{tabular}

The Portland cement paste was produced with a mixture of water and cement at a ratio of 0.5 . The fly ash-based geomaterial was produced from a mixture of liquid (alkali 
activator) and solid (fly ash) at a ratio of 0.5 . A mixture of a $9 \mathrm{M} \mathrm{NaOH}$ solution and a sodium silicate solution at a weight ratio of 1:1 was used as an alkali activator. The slagbased geomaterials were produced by replacing $50 \%$ of the fly ash with slag by weight. The slag-based geomaterials were produced with mixtures of liquid (alkali activator) and solid (fly ash and slag) at a ratio of 0.5 , identical to those of the other matrices. The alkali activator used for the slag-based geomaterials matrix was composed of a $4 \mathrm{M} \mathrm{NaOH}$ solution and a sodium silicate solution at a weight ratio of 2:1. The mixed samples were stirred for 3 to $5 \mathrm{~min}$. Then, they were transferred to a $200 \mathrm{~mL}$ Erlenmeyer flask, shaken in a water bath with a constant temperature $\left(25^{\circ} \mathrm{C}\right)$ for $24 \mathrm{~h}$, and cured for $7 \mathrm{~d}$. After drying at a constant temperature of $105^{\circ} \mathrm{C}$ for $24 \mathrm{~h}$, they were put into a cylindrical vial with a diameter of $25 \mathrm{~mm}$ and a height of $50 \mathrm{~mm}$.

In order to study the interaction between the adhesive matrix and cesium, a test sample containing stable cesium $\left({ }^{133} \mathrm{Cs}\right)$ was prepared. The analytical reagent $\mathrm{CsCl}$ was used to simulate radioisotopes $\left({ }^{137} \mathrm{Cs}\right)$. Then, $12.67 \mathrm{~g} \cdot \mathrm{L}^{-1}$ of $\mathrm{CsCl}$ was added to the adhesive, and up to $10 \mathrm{~g} \cdot \mathrm{L}^{-1}$ of $\mathrm{Cs}^{+}$were added, depending on the volume of the sample. Before mixing the samples, the $\mathrm{CsCl}$ was dissolved in the alkali activator.

\subsection{Characterization of the Adsorbent}

In this study, the material characterization methods were X-ray diffraction (XRD), scanning electron microscopy and energy dispersive spectrometer (SEM-EDS), and BrunauerEmmet-Teller (BET) surface area, pore volume, and pore size analysis.

In order to identify changes in the crystalline phase caused by incorporating cesium into the solidified matrix, XRD analysis was performed on the sample, and the XRD data were collected with a scan range of $5^{\circ}$ to $60^{\circ}$. The obtained characteristic diffraction peaks determined the type of crystal structure and material. The surface morphology and Cs distribution of the materials were observed by SEM-EDS. SEM was also used to determine the surface morphology of the materials. The BET surface area and pore size distribution were measured by $\mathrm{N}_{2}$ gas adsorption on the instrument. The sample was degassed at $150{ }^{\circ} \mathrm{C}$ for $3 \mathrm{~h}$ and was then subjected to a $\mathrm{N}_{2}$ adsorption/desorption test.

\subsection{Adsorption Experiments}

In order to study the effects of $\mathrm{pH}$, adsorbent usage, contact time, and initial concentration on the adsorption of $\mathrm{Cs}$, the following adsorption experiments were conducted. After the geomaterials were passed through a 720 mesh sieve, they were transferred to a $200 \mathrm{~mL}$ Erlenmeyer flask with $100 \mathrm{~mL}$ of Cs solution with a known concentration, and were then placed in a constant temperature shaker (TAITEC Plus Shaker EP ${ }^{-1}$ with Thermo Minder SX-10R, Saitama, Japan) set at a prescribed temperature. The temperature of the adsorption experiment was $25^{\circ} \mathrm{C}$, the $\mathrm{pH}$ values were $3,4,5,6,7,8$, and 9; the amounts of adsorbent used were $0.05 \mathrm{~g}, 0.1 \mathrm{~g}, 0.2 \mathrm{~g}, 0.4 \mathrm{~g}, 0.6 \mathrm{~g}$, and $0.8 \mathrm{~g}$; the contact times were $1 \mathrm{~h}, 3 \mathrm{~h}, 8 \mathrm{~h}, 24 \mathrm{~h}$, and $72 \mathrm{~h}$; and the initial concentrations were $5 \mathrm{mg} \cdot \mathrm{L}^{-1}, 10 \mathrm{mg} \cdot \mathrm{L}^{-1}, 20 \mathrm{mg} \cdot \mathrm{L}^{-1}, 30 \mathrm{mg} \cdot \mathrm{L}^{-1}$, and $40 \mathrm{mg} \cdot \mathrm{L}^{-1}$. The $\mathrm{pH}$ value was adjusted by using aqueous $\mathrm{HCl}$ and aqueous $\mathrm{NaOH}$.

Following each adsorption experiment, the suspension containing geomaterials and the above standard solution were filtered through a $0.45 \mu \mathrm{m}$ membrane filter (Mixed Cellulose Ester, $47 \mathrm{~mm}$, Advantec, Tokyo, Japan) to remove the $\mathrm{Cs}^{+}$that had been adsorbed into the geomaterials, and the concentration of the $\mathrm{Cs}$ in the filtrate was determined with the ICP-MS (Thermo Scientific Center: X-series II, Waltham, MA, USA). The adsorption capacity of the geomaterials for the Cs ions was calculated by Equation (1).

$$
q_{e}=\frac{\left(C_{i}-C_{e}\right)}{m} \cdot V
$$

where $q_{e}$ represents the adsorption capacity at equilibrium $\left(\mathrm{mg} \cdot \mathrm{g}^{-1}\right) ; C_{i}$ and $C_{e}$ are the initial and equilibrium $\mathrm{Cs}$ concentrations $\left(\mathrm{mg} \cdot \mathrm{L}^{-1}\right)$ in the solution, respectively; $V$ is the volume of the solution (L); and $m$ is the mass of adsorbent (g) [29-31]. 


\subsection{Adsorption Isotherm}

In the adsorption process, study of the equilibrium isotherm is necessary and crucial to predict the adsorption behavior of the pollutants towards the adsorbent surface. In this study, two common adsorption models, the Langmuir and Freundlich isotherm models, were used to evaluate adsorption data.

The Langmuir isotherm model assumes that the adsorption process occurs in a single layer of gas-solid two-phase adsorption and is given by Equation (2):

$$
\frac{C_{e}}{q_{e}}=\frac{C_{e}}{q_{\max }}+\frac{1}{K_{L} q_{\max }}
$$

where $C_{e}$ is the concentration of $C s$ in a batch system at equilibrium $\left(\mathrm{mg} \cdot \mathrm{L}^{-1}\right), q_{e}$ is the amount of $\mathrm{f} C \mathrm{~s}$ adsorption at equilibrium $\left(\mathrm{mg}^{-\mathrm{g}^{-1}}\right), q_{\mathrm{max}}$ is the maximum adsorption capacity of the adsorbent $\left(\mathrm{mg} \cdot \mathrm{g}^{-1}\right)$, and $K_{L}$ is the equilibrium adsorption constant $\left(\mathrm{L} \cdot \mathrm{mg}^{-1}\right)$. A plot of $C_{e} / q_{e}$ versus $C_{e}$ gives a straight line with a slope of $1 / q_{\max }$ and an intercept of $1 /\left(K_{L}\right.$ $\left.q_{\text {max }}\right) . K_{L}$ can be applied to the adsorption free energy $\Delta G_{\text {ads }}\left(\mathrm{J} \cdot \mathrm{mol}^{-1}\right)$ by Equation (3):

$$
n \Delta G_{\text {ads }}=-R T \ln K_{L}
$$

where $R$ is the gas constant $\left(8.314 \mathrm{~J} \cdot \mathrm{K}^{-1} \mathrm{~mol}^{-1}\right)$, $\mathrm{T}$ is the absolute temperature at equilibrium $(\mathrm{K})$, and $K_{L}$ is the equilibrium constant at temperature T.

The equilibrium constant $[32,33] K_{L}$ can be calculated according to Equation (4):

$$
K_{L}=q_{e} / C_{e}
$$

where $C_{e}$ and $q_{e}$ are the same as in Equation (2).

The Langmuir constant $\left(K_{L}\right)$ can be used to determine the suitability of the adsorbent for the adsorbate by using the dimensionless parameter of the Hall separation coefficient $\left(R_{L}\right)$, which is given by Equation (5):

$$
R_{L}=\left(\frac{1}{1+K_{L} C_{0}}\right)
$$

where $C_{0}\left(\mathrm{mg} \cdot \mathrm{L}^{-1}\right)$ is the initial concentration $[34,35]$.

The Freundlich isotherm model is a multi-layer adsorption process that does not consider adsorption saturation, which occurs on a multi-layer heterogeneous surface. The isotherm of the linear Freundlich model is expressed by Equation (6):

$$
\ln q_{e}=\ln K_{F}+(1 / n) \ln C_{e}
$$

where $K_{F}$ is the adsorption capacity $\left(\left(\mathrm{mg} \cdot \mathrm{g}^{-1}\right) \cdot\left(\mathrm{dm}^{-3} \cdot \mathrm{mg}^{-1}\right)^{1 / \mathrm{n}}\right)$, and $1 / n$ is the adsorption strength. The logarithmic scale graph of $q_{e}$ versus $C_{e}$ can be drawn to determine the $1 / n$ and $K_{F}$ values, and the value of $1 / n$ can be used to judge the difficulty of the adsorption process [36].

\subsection{Kinetic Studies}

The rate equation for a chemical reaction is an equation that links the reaction rate with concentrations or pressures of reactants and constant parameters (normally rate coefficients and partial reaction orders). For many reactions, the rate is given by a power law, such as Equation (7):

$$
r=k[\mathrm{~A}]^{x}[\mathrm{~B}]^{y}
$$

where $[\mathrm{A}]$ and $[\mathrm{B}]$ express the concentrations of the species $\mathrm{A}$ and $\mathrm{B}$, respectively (usually in moles per liter (molarity, M)). The exponents $x$ and $y$ are the partial reaction orders and must be determined experimentally; they are often not equal to the stoichiometric coefficients [32-35]. The constant $k$ is the rate coefficient or rate constant of the reaction. 
The value of this coefficient $k$ may depend on conditions such as the temperature, ionic strength, and surface area of an adsorbent or light irradiation.

A kinetic model has been proposed to determine the mechanism of the adsorption process, which provides useful data to improve the adsorption efficiency and the feasibility of scaling up the process $[37,38]$. In the present investigation, the mechanism of the adsorption process was studied by fitting pseudo-first-order and pseudo-second-order reactions to the experimental data.

The pseudo-first-order model is given by Equation (8):

$$
\ln \left(q_{e}-q_{t}\right)=\ln \left(q_{e}\right)-k_{1} t
$$

where $q_{e}$ and $q_{t}$ are the adsorption capacity $\left(\mathrm{mg}^{-\mathrm{g}^{-1}}\right)$ of the adsorbent to adsorb $\mathrm{Cs}^{+}$at the equilibrium time and time $t$, respectively, and $k_{1}$ is the rate constant $\left(\mathrm{h}^{-1}\right)$ of the pseudo-first-order adsorption.

The pseudo-second-order rate Equation (9) is expressed as follows:

$$
\frac{t}{q_{t}}=\frac{1}{k q_{e}^{2}}+\frac{t}{q_{e}}
$$

where $k$ is the rate constant of pseudo-secondary adsorption $\left(\mathrm{g} \cdot \mathrm{mg}^{-1} \cdot \mathrm{h}^{-1}\right)$, and where $q_{e}$ and $q_{t}$ are the adsorption capacity of adsorbent for $\mathrm{Cs}^{+}$at the equilibrium time and time $t$, respectively $\left(\mathrm{mg} \cdot \mathrm{g}^{-1}\right)$.

\section{Results and Discussion}

\subsection{Adsorption Experiment}

\subsubsection{Effect of $\mathrm{pH}$ on the Adsorption of $\mathrm{Cs}$}

The $\mathrm{pH}$ value of the aqueous solution will affect the surface charge of the adsorbent, the ionization degree and morphology of the metal ions, and the surface metal-binding sites. Under the conditions of the $\mathrm{pH}$ values of 3, 4, 5, 6, 7, 8, and 9, all other parameters were kept unchanged (adsorbent usage: $0.1 \mathrm{~g}$; contact time: $24 \mathrm{~h}$; initial concentration: 0.79 $\mathrm{mg} \cdot \mathrm{L}^{-1}$; and temperature: $298 \mathrm{~K}$ ). The effect of $\mathrm{pH}$ on the adsorption of $\mathrm{Cs}^{+}$was studied. The results are shown in Figure 1. The maximum adsorption capacity of $\mathrm{Cs}^{+}$was obtained at $\mathrm{pH} 8$, which may be related to the alkaline nature of the geomaterials. Therefore, a $\mathrm{pH}$ of 8 was selected for further study.

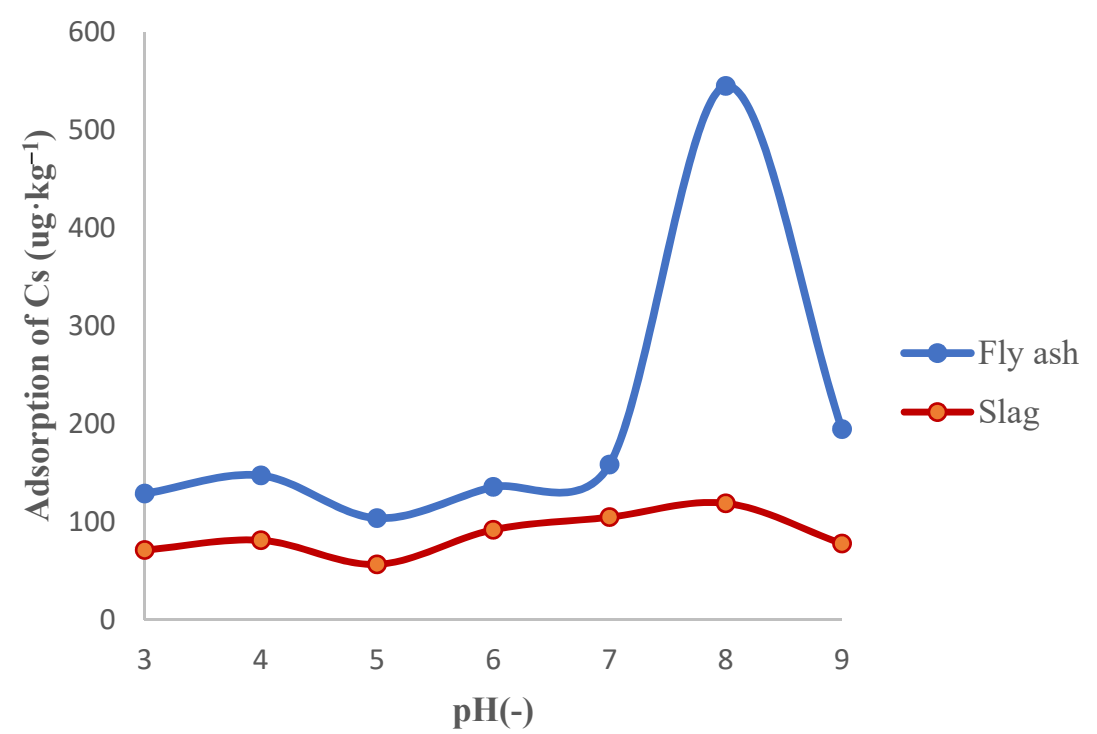

Figure 1. Effect of $\mathrm{pH}$ on the adsorption of $\mathrm{Cs}$ by fly ash-based geomaterials and slag-based geomaterials. 


\subsubsection{Effect of the Adsorbent Dosage on the Adsorption of Cs}

The amount of adsorbent used is an important factor affecting the adsorption capacity. In order to determine the effect of the amount of adsorbent on the removal of $\mathrm{Cs}^{+}$, the adsorbent dosage was varied $(0.05 \mathrm{~g}, 0.1 \mathrm{~g}, 0.2 \mathrm{~g}, 0.4 \mathrm{~g}, 0.6 \mathrm{~g}$, and $0.8 \mathrm{~g})$ under other fixed conditions (temperature: $298 \mathrm{~K}$; contact time: $24 \mathrm{~h}$; and initial concentration: $0.79 \mathrm{mg} \cdot \mathrm{L}^{-1}$ ). The results are shown in Figure 2. It can be seen from the figure that as the adsorbent dosage increased, the removal rate increased significantly. For the adsorbent dosage of $0.6 \mathrm{~g}$, it can be observed that more than $80 \%$ of $\mathrm{Cs}^{+}$was removed; when the adsorbent dosage was greater than $0.6 \mathrm{~g}$, the adsorption capacity did not increase significantly. Therefore, $0.6 \mathrm{~g}$ was considered to be the optimal dosage for Cs adsorption for further study.

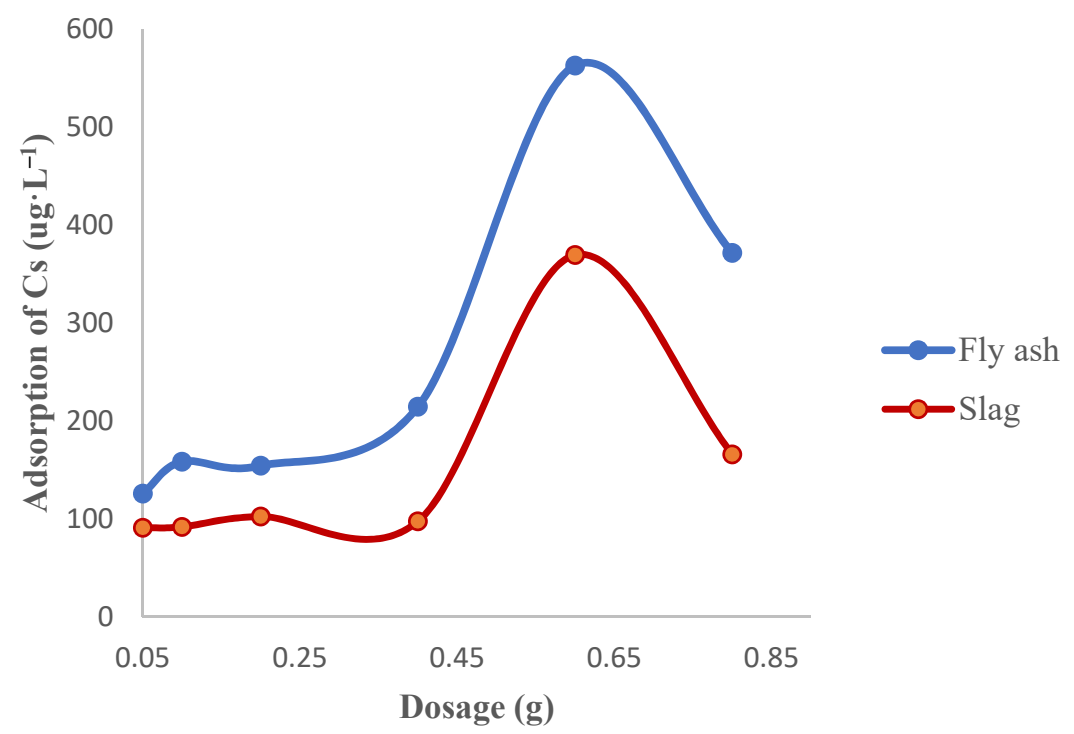

Figure 2. Effect of sorbent dosage on the adsorption of Cs by fly ash-based geomaterials and slagbased geomaterials.

\subsubsection{Effect of Contact Time on the Adsorption of Cs}

The influence of contact time on Cs adsorption by the geomaterials was explored. In this study, the adsorption of $0.79 \mathrm{mg} \cdot \mathrm{L}^{-1}$ of $\mathrm{Cs}^{+}$was conducted using $0.6 \mathrm{~g}$ of adsorbent under the conditions of a temperature of $25^{\circ} \mathrm{C}$ and a pH of 8 . The $\mathrm{Cs}^{+}$adsorption amount by the geomaterials was measured when the contact time was $1 \mathrm{~h}, 3 \mathrm{~h}, 8 \mathrm{~h}, 24 \mathrm{~h}$, and $72 \mathrm{~h}$, and the results are shown in Figure 3 This study also verified the kinetics of the adsorption process, which are presented in Section 3.3. It was observed that the Cs adsorption capacity of the geomaterials increased sharply in the first $3 \mathrm{~h}$, and until the contact time of $24 \mathrm{~h}$, the adsorption capacity of Cs gradually increased; there was no significant change thereafter. Therefore, $24 \mathrm{~h}$ was chosen as the best contact time for further study.

\subsection{Characterization of Geomaterials}

The influence of the doped Cs on the crystal structure of the adhesive was investigated by XRD, and the results are shown in Figure 4. In the Portland cement binder, the addition of Cs did not cause the formation of a crystalline phase but led to the formation of Friedel's salt, which was due to the sulfate ion in monosulfate (AFm) or ettringite (AFt) being replaced by a chloride ion. This indicates that the chloride ions from cesium chloride resulted in the formation of Friedel's salt $[37,38]$. In the fly ash-based geomaterials, the crystalline phases were mullite, quartz, coesite, hematite, and magnetite, that is, the non-reactive crystalline phase present in the original fly ash. The crystalline phase in the slag-based geomaterials was similar to the fly ash-based geomaterials, and the peak corresponding to $\mathrm{C}-\mathrm{S}-\mathrm{H}$ increased with increasing the slag content. No cesium-containing 
crystalline phase was observed, which is similar to the results of the Portland cement and the fly ash-based geomaterials.

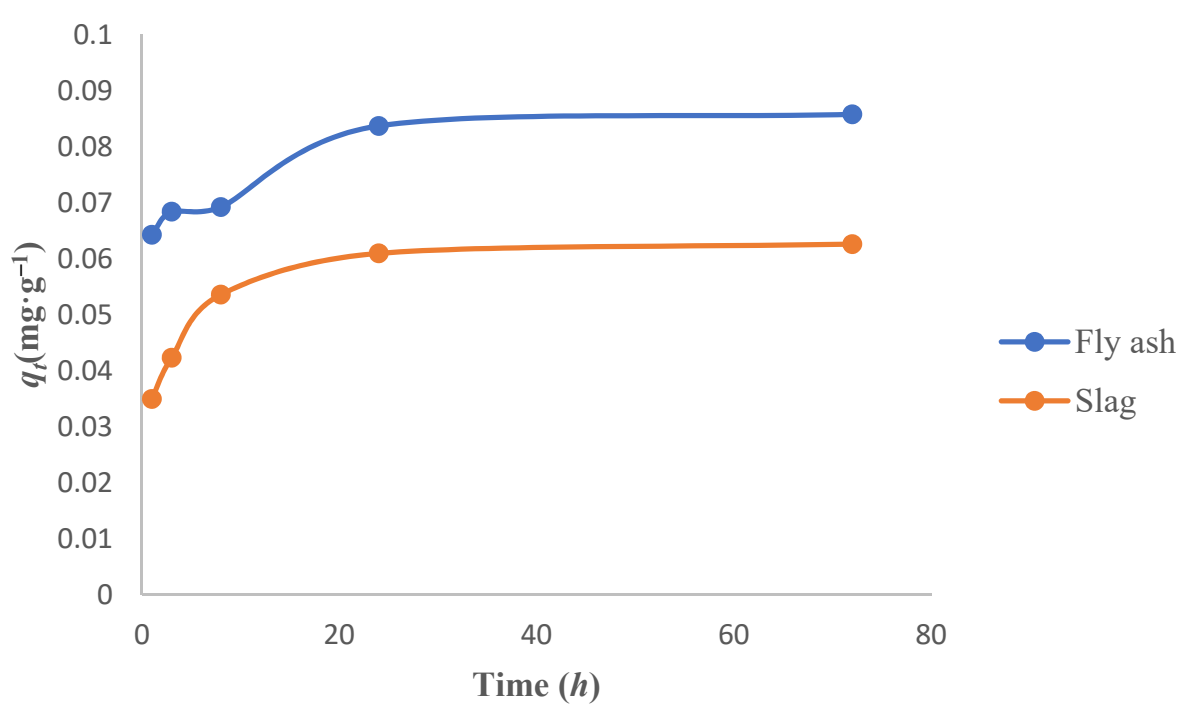

Figure 3. Adsorption capacity of fly ash-based geomaterials and slag-based geomaterials for Cs adsorption.

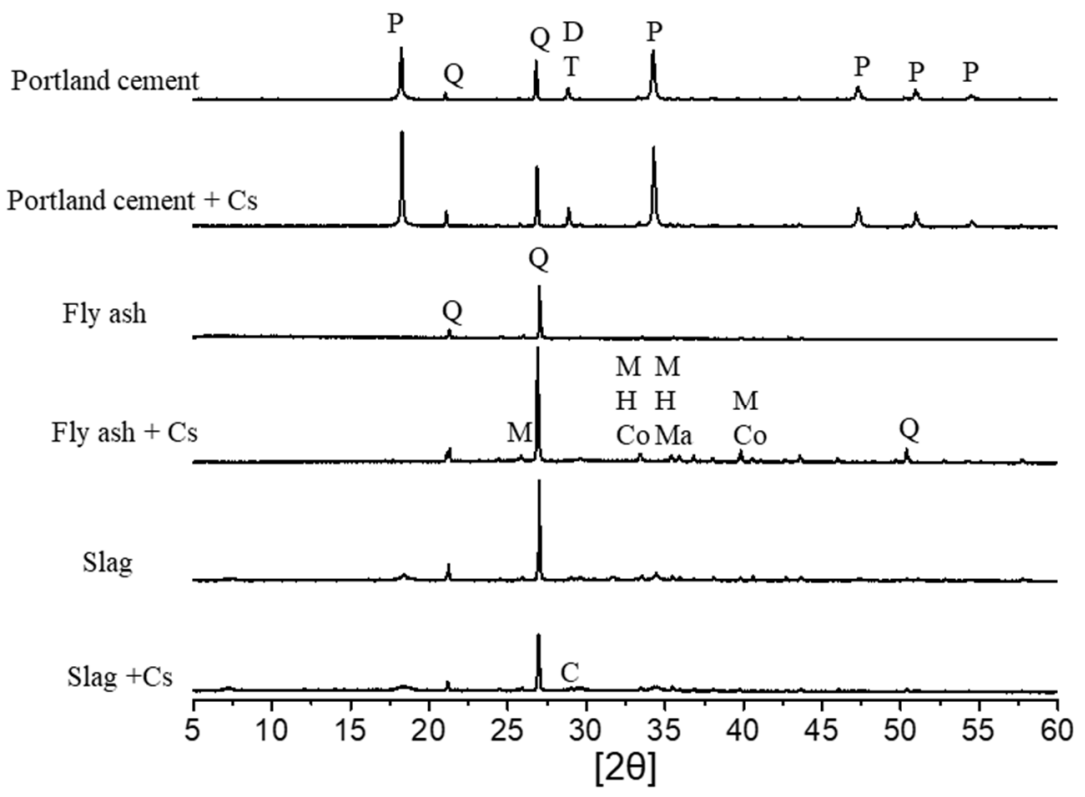

Figure 4. XRD of some geomaterials before and after the incorporation of Cs. P: portlandite, $\mathrm{H}$ : hematite, Ma: magnetite, C: C-S-H, M: mullite, Q: quartz, Co: coesite, T: tricalcium silicate, D: dicalcium silicate.

The SEM and element mapping of the geomaterial matrices are shown in Figure 5. From the SEM images, we can see the flocculated substance and crystal, among which the flocculated substance is amorphous silicon aluminate. The SEM images of the Portland cement and slag-based geomaterials show that the whole material structure is relatively compact, and the pores are small. The morphological characteristics of fly ash-based geomaterials is similar to that of Zhao [39], who used alkali slag-modified alkali to stimulate fly ash-based geopolymer gels, but the pores of the fly ash-based geomaterials are larger. The white sediment in the geomaterials may be formed by Cs, which is evenly distributed, and the location is not concentrated. It is important to note a negative correlation between 
Cs and $\mathrm{Na}$ can be found in the element mapping image. This correlation could be the evidence of the typical cation exchange reactions that occur in geotechnical materials, in which sodium zeolite or its precursor exchanges its charge-balanced cations. Specifically, molecular sieves or their precursors serve as adsorption sites where sodium is replaced by cesium $[40,41]$.
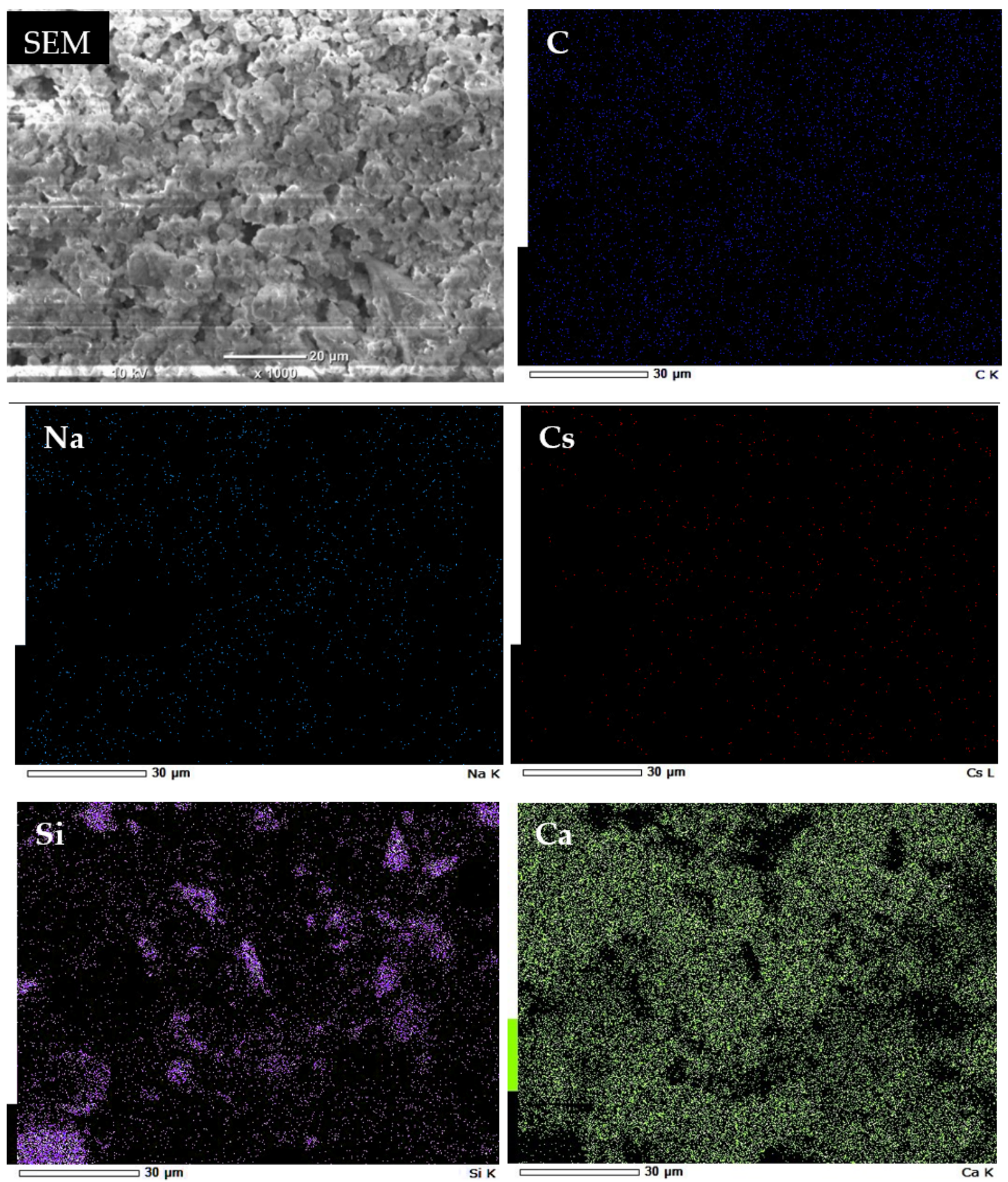

(A)

Figure 5. Cont. 

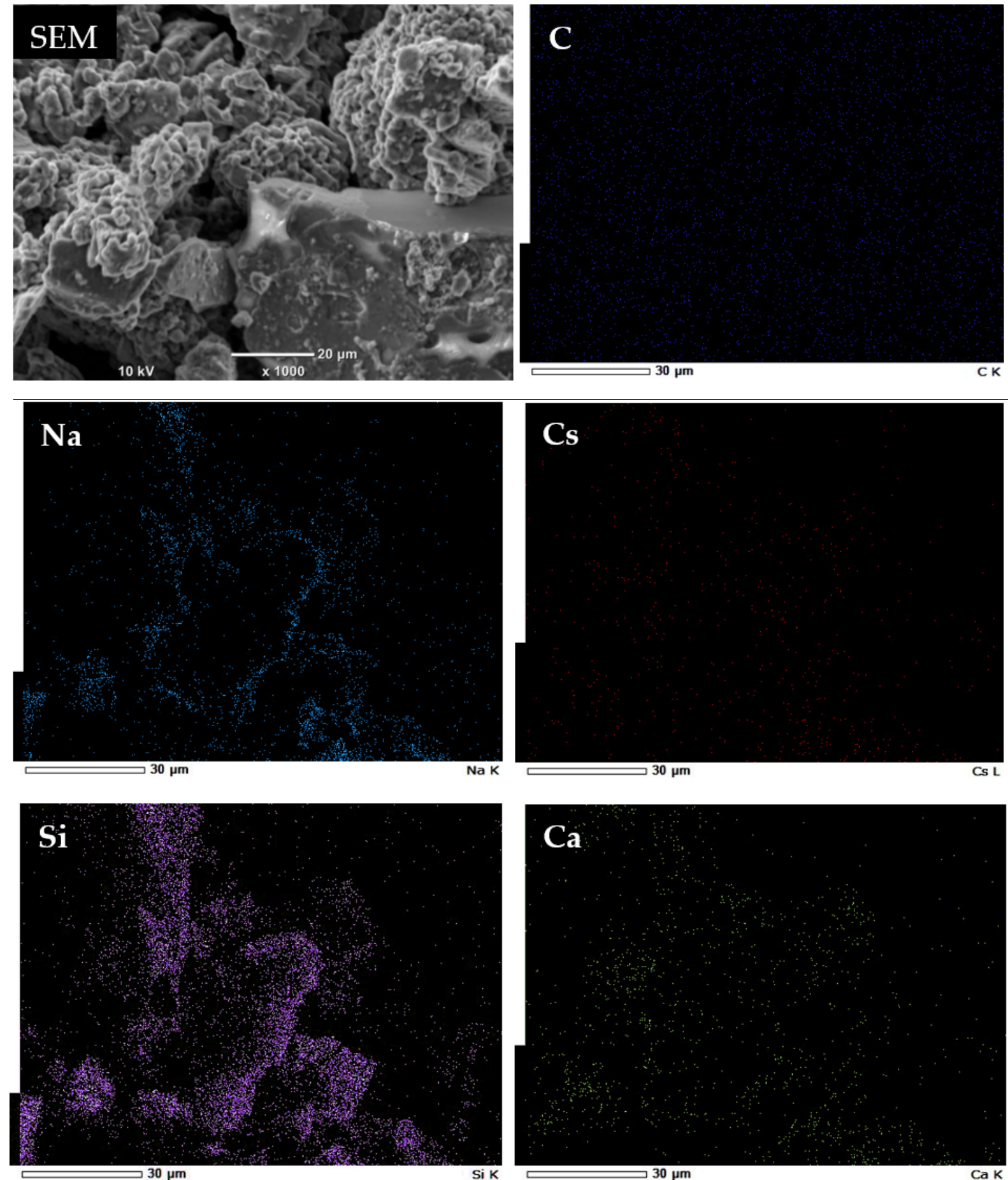

(B)

Figure 5. Cont. 

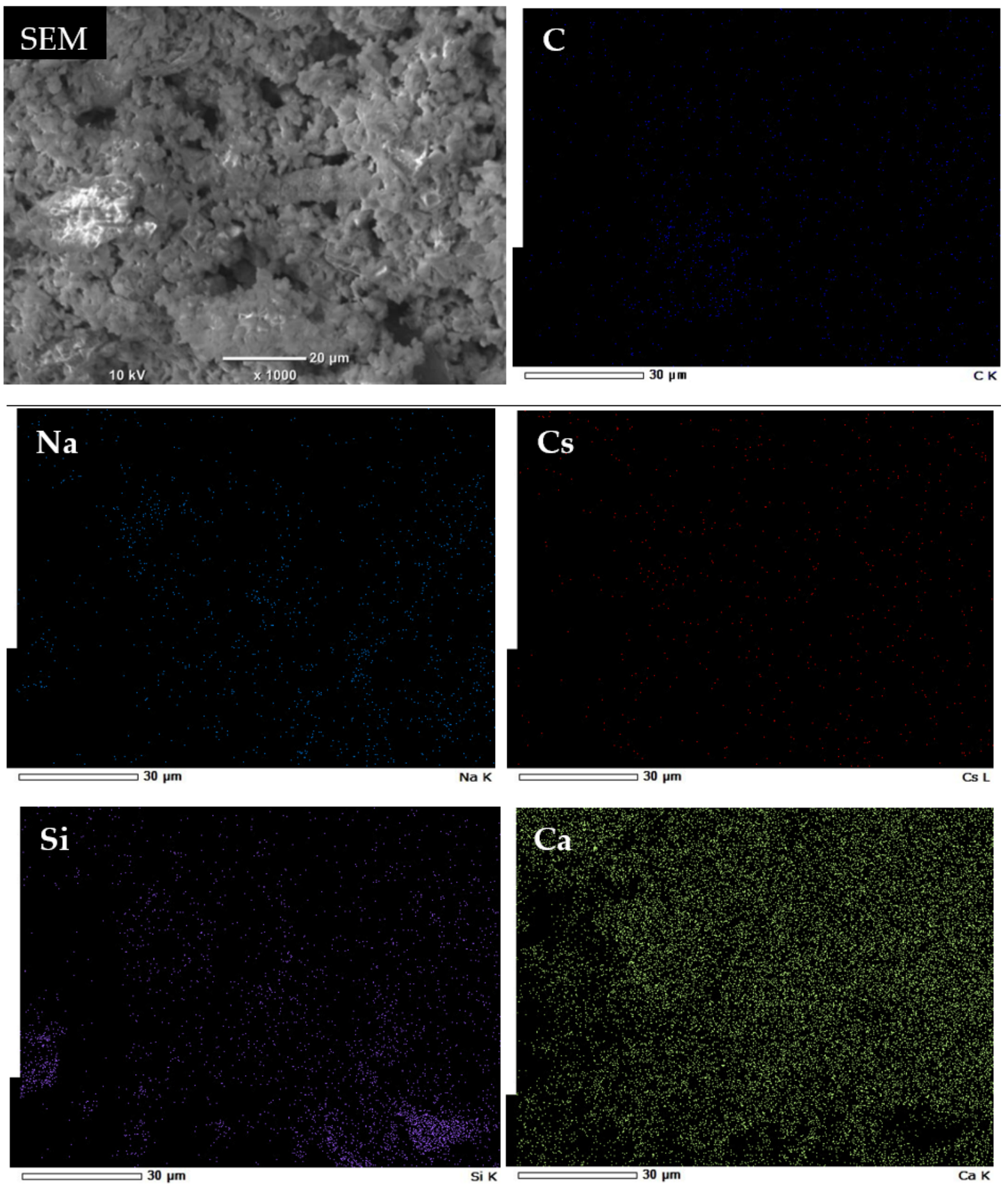

(C)

Figure 5. SEM and element mapping images of the geomaterial matrices. (A) Portland cement, (B) fly ash, (C) slag.

The specific surface areas of ordinary Portland cement, fly ash-based geomaterials, and slag-based geomaterials were measured by $\mathrm{N}_{2}$ adsorption. The pore characteristics of the powder binder determined by the BET method are summarized in Table 2. These results indicate that the fly ash-based geomaterials had the highest surface area and micropore volume and that the pore characteristics of the fly ash-based geomaterials were the most suitable for the adsorption of Cs, which is consistent with the SEM results. This also indicates that fly ash-based geomaterials may be the most effective in terms of chemical barriers to prevent the release of cesium. 
Table 2. The BET surface area, pore size, and pore volume of Portland cement, fly ash, and slag.

\begin{tabular}{cccc}
\hline Sample & $\begin{array}{c}\text { BET Surface Area } \\
{\left[\mathbf{m}^{\mathbf{2}} \cdot \mathbf{g}^{-\mathbf{1}]}\right.}\end{array}$ & $\begin{array}{c}\text { Pore Volume } \\
{\left[\mathbf{c m}^{\mathbf{3}} \cdot \mathbf{g}^{-\mathbf{1}]}\right.}\end{array}$ & $\begin{array}{c}\text { Pore Size } \\
{[\mathbf{n m}]}\end{array}$ \\
\hline Portland Cement & 0.9582 & 0.002652 & 11.07 \\
Slag & 1.388 & 0.004432 & 12.77 \\
Fly Ash & 1.869 & 0.006359 & 13.61 \\
\hline
\end{tabular}

\subsection{Adsorption Kinetics Study}

The adsorption kinetics study was conducted to explore the relationship between the adsorption amount $q_{t}$ and $t$. As seen in Figure 3, the adsorption capacity of the fly ashbased and slag-based geomaterials on $\mathrm{Cs}^{+}$increased significantly within $24 \mathrm{~h}$. In order to understand the adsorption kinetics in more detail, the mechanism of the adsorption process was studied by fitting the pseudo-first-order reactions and pseudo-secondary reactions to the experimental data of this study. In order to investigate the consistency between the model and the experimental results under the optimized experimental conditions, the pseudo-first-order and pseudo-secondary results were used to apply the linear graphs of $\ln \left(q_{e}-q_{t}\right)-t$ and $t / q_{t}-t$ to the Cs adsorption kinetic model, as shown in Figures 6 and 7 , respectively. Table 3 shows the linear constants $\left(R^{2}\right)$ and the other parameters of the two kinetic models of $\mathrm{Cs}^{+}$adsorption to geomaterials calculated from Figures 6 and 7 . For the cesium adsorption kinetics of the slag-based geomaterials, the pseudo-first-order model has a higher $R^{2}$ value than that of the pseudo-second-order model, indicating that the adsorption process was mainly physical adsorption. On the other hand, the Cs adsorption kinetics of the fly ash-based geomaterials is in good agreement with the pseudo-secondary model, which indicates that chemical adsorption was more dominant. This can be explained by the fact that the fixation mechanism of Cs in alkali-activated fly ash is controlled by the cation exchange mechanism [42].

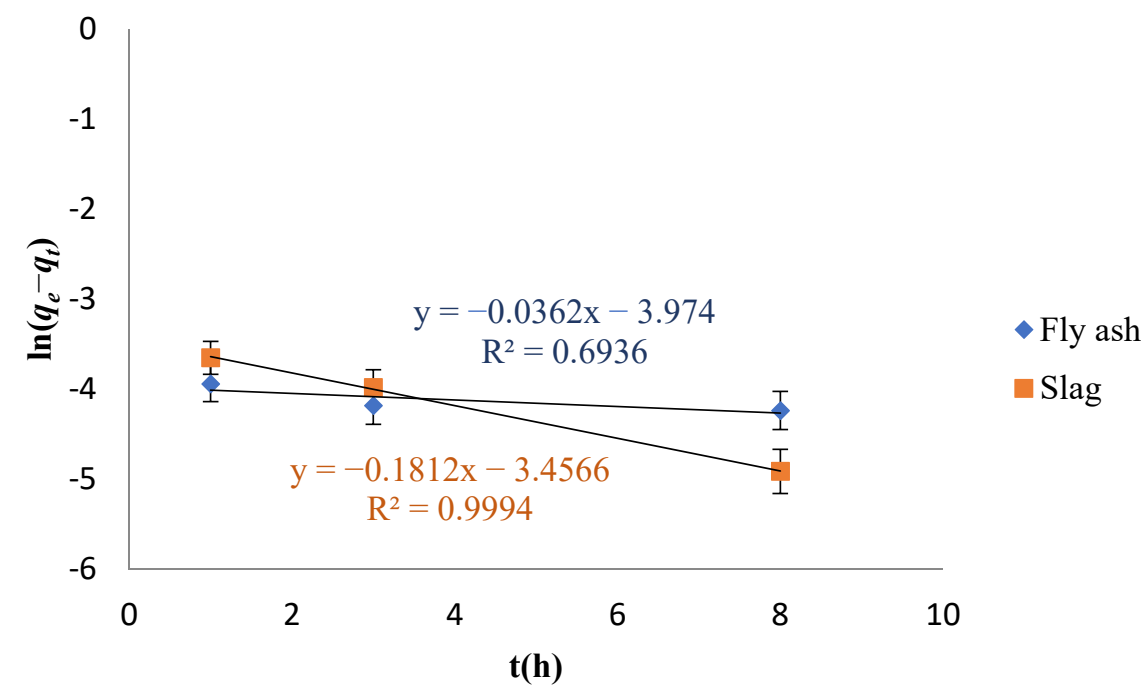

Figure 6. Pseudo-first-order linear kinetic model of Cs adsorption on the fly ash-based geomaterials and slag-based geomaterials. 


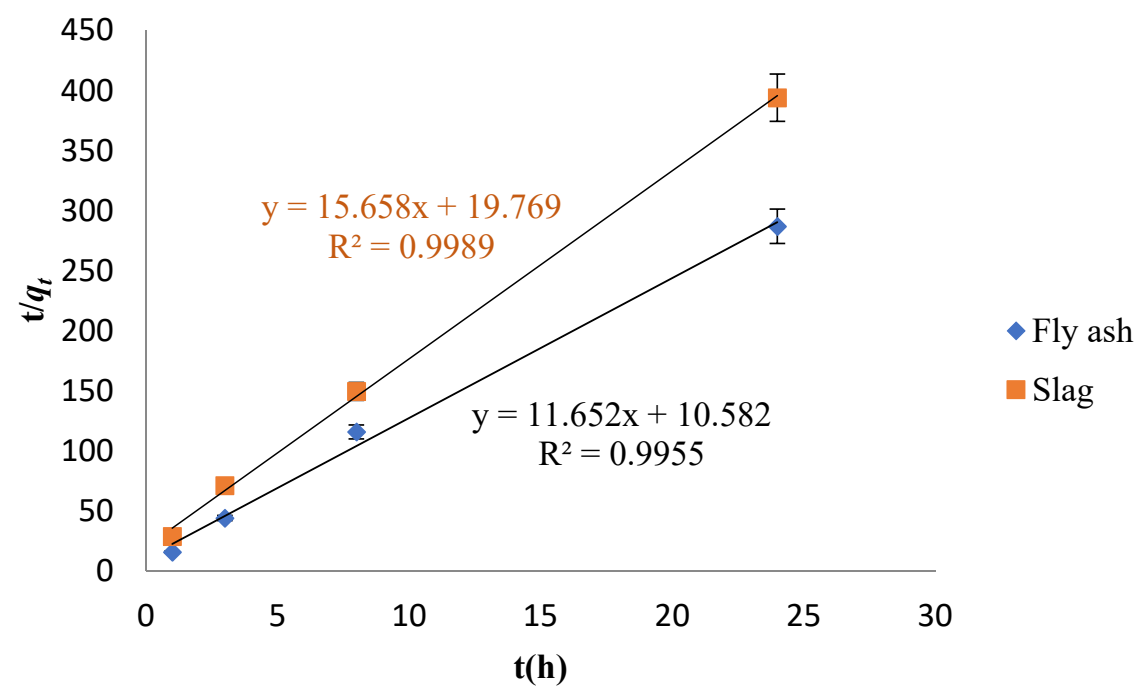

Figure 7. Pseudo-second-order linear kinetic model of Cs adsorption on the fly ash-based geomaterials and slag-based geomaterials.

Table 3. Parameters for two kinetic models of Cs adsorption by fly ash-based geomaterials and slag-based geomaterials.

\begin{tabular}{|c|c|c|c|c|c|c|c|}
\hline \multirow[b]{2}{*}{ Sample } & \multirow[b]{2}{*}{$\begin{array}{c}q_{\exp } \\
(\mathrm{mg} / \mathrm{g})\end{array}$} & \multicolumn{3}{|c|}{ Pseudo-First-Order } & \multicolumn{3}{|c|}{ Pseudo-Second-Order } \\
\hline & & $\begin{array}{c}q_{\mathrm{e}} \\
\left(\mathrm{mg} \cdot \mathrm{g}^{-1}\right)\end{array}$ & $\begin{array}{c}k_{1} \\
\left(\mathrm{~h}^{-1}\right)\end{array}$ & $R^{2}$ & $\begin{array}{c}q_{e} \\
\left(\mathrm{mg} \cdot \mathrm{g}^{-1}\right)\end{array}$ & $\begin{array}{c}k_{2} \\
\left(\mathrm{~g} \cdot \mathrm{mg}^{-1} \cdot \mathrm{h}^{-1}\right)\end{array}$ & $R^{2}$ \\
\hline Fly ash & 83.68 & 53.20 & 0.03620 & 0.6936 & 85.82 & 12.83 & 0.9955 \\
\hline Slag & 60.93 & 60.67 & 0.1812 & 0.9994 & 31.71 & 12.40 & 0.9989 \\
\hline
\end{tabular}

\subsection{Adsorption Isotherm Study}

The adsorption isotherm is usually used to reflect the performance of the adsorbent in the adsorption process. In order to quantify the adsorption capacity of the adsorbent to remove Cs, Langmuir and Freundlich's isotherms were used in this study. Under optimal adsorption conditions ( $\mathrm{pH}$ of 8 , contact time of $24 \mathrm{~h}$, adsorbent dosage of $0.6 \mathrm{~g}$ ), the adsorption isotherm model of $\mathrm{Cs}^{+}$on the geopolymer was established at the initial concentrations of $5 \mathrm{ppm}, 10 \mathrm{ppm}, 20 \mathrm{ppm}, 30 \mathrm{ppm}$, and $40 \mathrm{ppm}$. The results of the adsorption data investigated by the Langmuir and Freundlich models are shown in Figures 8 and 9, respectively. Other parameters, including the correlation coefficient $\left(R^{2}\right)$, are given in Table 4 . The correlation coefficient shows that the Langmuir isotherm can describe the adsorption of Cs better than Freundlich's isotherm model can. This result shows that the adsorption of $\mathrm{Cs}^{+}$by geomaterials mainly occurs through a single-layer reaction, and the maximum adsorption capacity is estimated to be $89.32 \mathrm{mg} \cdot \mathrm{g}^{-1}$. The attached isotherm parameters show that the fly ash-based geomaterials are more effective for adsorbing $\mathrm{Cs}$ ions.

Table 4. Coefficient of Langmuir and Freundlich isotherms for Cs.

\begin{tabular}{|c|c|c|c|c|c|c|}
\hline \multirow[b]{2}{*}{ Sample } & \multicolumn{3}{|c|}{ Langmuir Isotherm } & \multicolumn{3}{|c|}{ Freundlich Isotherm } \\
\hline & $\underset{\left(\mathrm{mg} \cdot \mathrm{g}^{-1}\right)}{q_{\max }}$ & $\begin{array}{c}K_{L} \\
\left(\mathrm{~L} \cdot \mathrm{mg}^{-1}\right)\end{array}$ & $R^{2}$ & $\begin{array}{c}K_{F} \\
\left(\left(\mathrm{mg}^{-1} \mathrm{~g}^{-1}\right)\right. \\
\left.\left(\mathrm{dm}^{-3} \cdot \mathrm{mg}^{-1}\right)^{1 / n}\right)\end{array}$ & $1 / n$ & $R^{2}$ \\
\hline Fly ash & 89.32 & 0.1665 & 0.9948 & 10.75 & 0.01620 & 0.1309 \\
\hline Slag & 44.52 & 0.02126 & 0.9954 & 20.55 & 0.04660 & 0.3698 \\
\hline
\end{tabular}




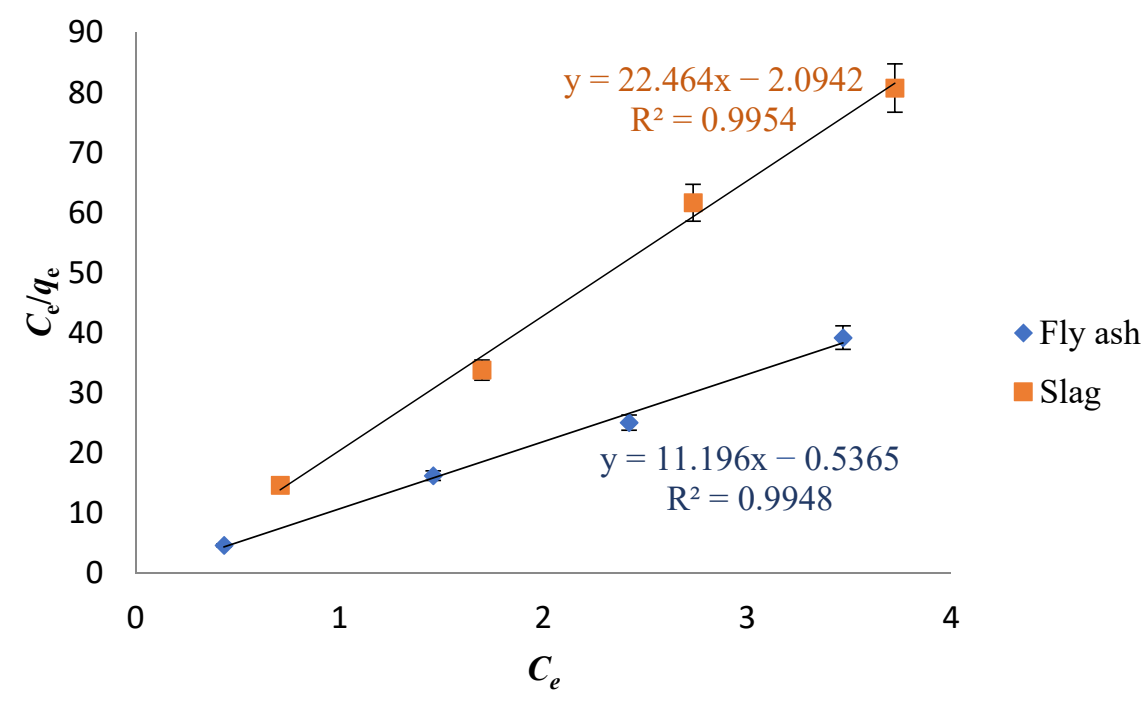

Figure 8. The Cs adsorption of the Langmuir isotherm on the fly ash-based geomaterials and slag-based geomaterials.

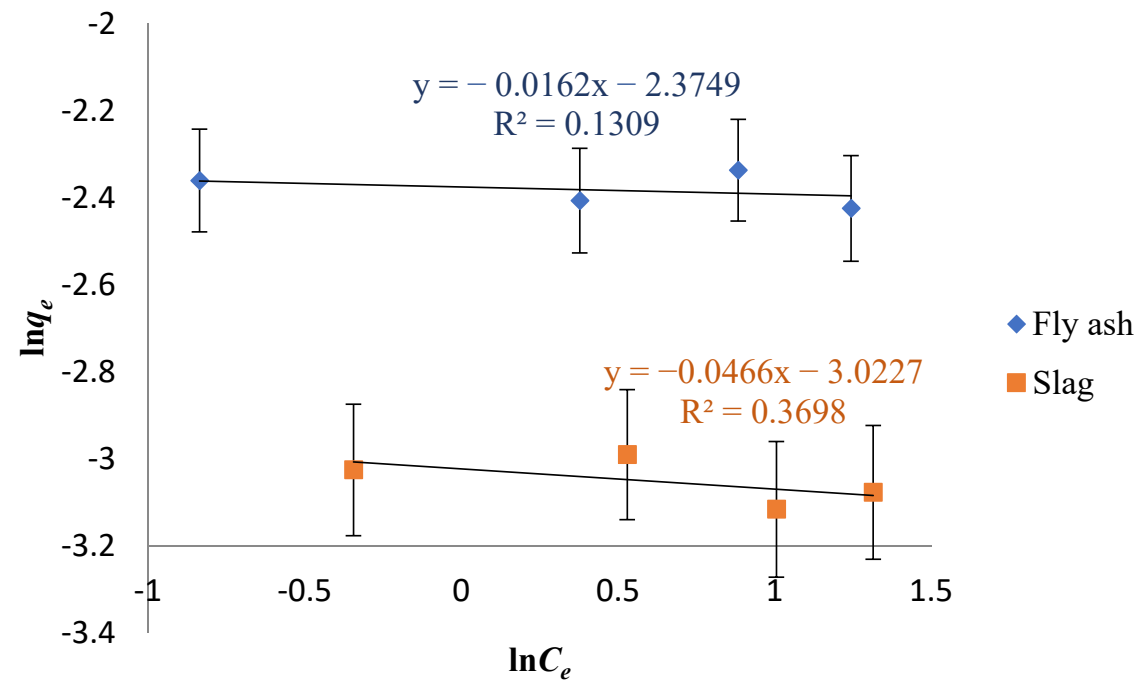

Figure 9. The Cs adsorption of the Freundlich isotherm on the fly ash-based geomaterials and slag-based geomaterials.

\subsection{Adsorption Mechanism}

The adsorption of cesium on fly ash-based geomaterials and geomaterials doped with slag was studied. The influence of the $\mathrm{pH}$ of the solution, the adsorbent dosage, and the contact time on the adsorption efficiency were discussed. The following matters can be considered:

(1) The adsorption experiment data of Cs on fly ash-based geomaterials and slag-based geomaterials conform to the Langmuir isotherm adsorption equation. The isothermal fitting of the Langmuir model shows that the surface is heterogeneous, which indicates that the adsorption of Cs on the surface of the adsorbent mainly occurred as singlelayer adsorption.

(2) The best fit was obtained with the pseudo-second-order kinetic model while investigating the adsorption kinetics of Cs adsorption on the fly ash-based geomaterials, indicating that the adsorption process was mainly chemical adsorption. The $R^{2}$ was greater than 0.996. On the other hand, Cs adsorption on the slag-based geomaterials was suitably described by the pseudo-first-order model as well as by the pseudo- 
second-order model (the $R^{2}$ values were both about 0.999 ), indicating that physical as well as chemical adsorption were dominant in the adsorption process.

The results show that the fly ash-based geomaterials can remove $\mathrm{Cs}^{+}$more effectively. The adsorption kinetics of the geomaterials with higher adsorption capacities are compatible with the pseudo-two-stage kinetic model, which indicates that it is controlled by complex multi-step adsorption. The negative correlation between cesium and sodium is evidence of a typical cation exchange reaction that occurs in fly ash-based geomaterials, in which sodium zeolite or its precursor exchanges its charge-balancing cations. Specifically, zeolite or its precursor is provided as an adsorption site, where sodium is replaced by cesium $[40,41]$. Calcium silicate hydrate geomaterials may interact with the adsorbate by a weak interaction through van der Waals forces (i.e., Physisorption). On the other hand, the (sodium)-aluminosilicate-hydrate geomaterials may share or exchange electrons (cations) between the adsorbent and the adsorbate (i.e., Chemisorption). These results provide new insights, demonstrating that the properties of aluminosilicate geomaterials with a large microporous surface area promote more effective cesium fixation compared to calcium silicate hydrate.

\subsection{Comparison with Other Adsorbents}

For many adsorption studies, the performance of the adsorbent is generally estimated and expressed by the maximum (or equilibrium) adsorption capacity. However, the maximum adsorption capacity is sensitively affected by the initial loading concentration of target pollutant (or more specifically what is left after sorption reaction).

(If the sorbent is exposed to a higher concentration of targets, it is apt to exhibit a higher adsorption capacity. On the other hand, if the sorbent is exposed to lower levels of target species, it will show lower capacities.)

Then, in addition to the maximum adsorption capacity, it is effective to estimate using the concept of partition coefficient (PC) as explained below as the following our references.

$\mathrm{PC}=$ Adsorption capacity/Final concentration

(or $=$ Adsorption capacity $/($ Initial concentration $\times$ removal ratio $)$.

From Table 5, it can be seen that the maximal adsorption capacity of the fly ashbased geomaterial in this study is not notably high $\left(89.32 \mathrm{mg} \cdot \mathrm{g}^{-1}\right)$ compared to the other adsorbents. However, it is noteworthy that the PC value of this adsorbent is fairly high $\left(31.02 \mathrm{mg} \cdot \mathrm{g}^{-1} \cdot \mathrm{mM}^{-1}\right)$. It can then be regarded as a potential adsorbent for treating Cs in wastewater for practical use, especially when also considering that the synthesis method of the adsorbent is simple.

Table 5. The comparison of adsorption properties of several adsorbents.

\begin{tabular}{|c|c|c|c|c|}
\hline Adsorbents & $\begin{array}{l}\text { Final Concentration } \\
\left(\mathrm{mg} \cdot \mathrm{L}^{-1}\right)\end{array}$ & $\begin{array}{l}\text { Adsorption Capacity } \\
\qquad\left(\mathrm{mg} \cdot \mathrm{g}^{-1}\right)\end{array}$ & $\begin{array}{l}\text { Partition Coefficient } \\
\quad\left(\mathrm{mg} \cdot \mathrm{g}^{-1} \cdot \mathrm{mM}^{-1}\right)\end{array}$ & Reference \\
\hline $\mathrm{nFe} / \mathrm{Cu}-\mathrm{Z}$ & 26.28 & 77.51 & 2.949 & [43] \\
\hline Natural clinoptilolite from Serbia & 76.00 & 49.26 & 0.6482 & [44] \\
\hline Nanocrystalline mordenite (pulverized) & 4.000 & 37.30 & 9.325 & [45] \\
\hline MWCNT reinforced zeolite-A beads & 30.00 & 113.0 & 3.767 & [46] \\
\hline Carbon-zeolite & 156.0 & 120.9 & 0.7750 & {$[47]$} \\
\hline Natural mordenite & 9.574 & 254.8 & 26.61 & [48] \\
\hline Synthetic mordenite & 9.508 & 220.4 & 23.18 & [48] \\
\hline $\begin{array}{l}\text { Phosphoric acid activated } \\
\text { montmorillonite }\end{array}$ & 13.30 & 208 & 15.64 & [49] \\
\hline Ethyl-VER & 2.161 & 43.96 & 20.34 & [50] \\
\hline Bentonite & 8.700 & 177.4 & 20.39 & [51] \\
\hline Clinoptilolite & 12.50 & 12.50 & 1.000 & {$[52]$} \\
\hline Fly ash-based geomaterials & 2.879 & 89.32 & 31.02 & This study \\
\hline
\end{tabular}

In recent years, a lot of research has focused on the solidification of radioactive waste-based on geomaterials, but the current understanding of the fixing mechanism 
is not necessarily sufficient. This study mentioned the fixation mechanism of Cs in the solidification of geomaterials, especially in terms of chemistry.

\section{Conclusions}

Based on the static adsorption test, the adsorption performance of Cs on geomaterials was studied, and the influence of various factors on the adsorption performance was discussed. Constructing the foundation for the further solidification of waste containing radioactive elements was examined in this work. The geomaterials were synthesized from fly ash and slag, and the synthesized geomaterials were characterized by XRD, SEM, and $\mathrm{N}_{2}$-BET. The adsorption efficiency of the fly ash-based geomaterials and the geomaterials doped with slag as adsorbents for removing $\mathrm{Cs}$ was evaluated. The effects of the $\mathrm{pH}$, adsorbent dosage, and contact time on Cs removal were investigated. Furthermore, the Langmuir and Freundlich models were used to describe the adsorption equilibrium mathematically. From this work, the fly ash-based geomaterials showed a maximum Cs adsorption capacity of $89.32 \mathrm{mg} \cdot \mathrm{g}^{-1}$ and a high PC of $31.02 \mathrm{mg} \cdot \mathrm{g}^{-1} \cdot \mathrm{mM}^{-1}$ for Cs. Additionally, the applicability of the kinetic model to the adsorption process was also discussed.

Through this work, it was proved to a certain extent that the fly ash-based geomaterials adsorb Cs more efficiently and that they have considerable potential to be applied as adsorbents for removing Cs. Furthermore, the immobilization of $\mathrm{Cs}$ in geomaterials was explored from a chemical perspective. From the perspective of environmental protection, fly ash can be used to treat nuclear waste containing radioactive nuclear waste liquid. In conclusion, fly ash based-geomaterials may be a promising option for the treatment and disposal of nuclear-contaminated waste.

Author Contributions: Experiment, data evaluation, and writing, H.Z.; instruments of measurement, M.Z.; experiment and data evaluation, X.D.; experiment and data evaluation, S.F.; instruments of measurement and data evaluation, N.M.; supervision and writing, N.K. All authors have read and agreed to the published version of the manuscript.

Funding: The present work was partially supported by a Grant-in-Aid for Scientific Research from the Japan Society for the Promotion of Science (Research Program (C), No. 21K12290).

Institutional Review Board Statement: Not applicable.

Informed Consent Statement: Not applicable.

Acknowledgments: The authors are grateful to Ohizumi, M. from the Office for Environment and Safety and to Iwafune of the Common Facility Infrastructure Center. The authors are also grateful to Teraguchi, M.; Nomoto, T.; Tanaka, T.; and Hatamachi, T. from the Facility of Engineering at Niigata University for permitting the use of the ICP-MS, XRD, FT-IR, SEM-EDS, and the surface area analyzer.

Conflicts of Interest: The authors declare no conflict of interest.

\section{References}

1. Kitto, M.E.; Marrantino, J.C.; Fielman, E.M.; Haines, D.K.; Semkow, T.M.; Bari, A. Long-term monitoring of radioactivity in fish from New York waters. J. Environ. Radioact. 2015, 146, 44-50. [CrossRef]

2. Ghandhi, S.A.; Weber, W.; Melo, D.; Doyle-Eisele, M.; Chowdhury, M.; Guilmette, R.; Amundson, S.A. Effect of 90 Sr internal emitter on gene expression in mouse blood. BMC Genom. 2015, 16, 586. [CrossRef]

3. Strand, P.; Sundell-Bergman, S.; Brown, J.E.; Dowdall, M. On the divergences in assessment of environmental impacts from ionizing radiation following the Fukushima accident. J. Environ. Radioact. 2017, 169-170, 159-173. [CrossRef] [PubMed]

4. Aliyu, A.S.; Nikolaos, E.; Timothy, A.M.; Wu, J.; Ramli, A.T. An overview of current knowledge concerning the health and environmental consequences of the Fukushima Daiichi Nuclear Power Plant (FDNPP) accident. Environ. Int. 2015, 7, $213-228$. [CrossRef]

5. Buesseler, K.O.; Dai, M.; Aoyama, M.; Benitez-Nelson, C.; Charmasson, S.; Higley, K.; Maderich, V.; Masqué, P.; Morris, P.J.; Oughton, D.; et al. Fukushima Daiichiderived radionuclides in the ocean-transport. Annu. Rev. Mar. Sci. 2016, 9, 173-203. [CrossRef]

6. Buesseler, K.; Aoyama, M.; Fukasawa, M. Impacts of the Fukushima Nclear Power Plants on marine radioactivity. Environ. Sci. Technol. 2011, 45, 9931-9935. [CrossRef] 
7. Hodkin, D.J.; Stewart, D.I.; Graham, J.T.; Burke, I.T. Coprecipitation of 14C and Sr with carbonate precipitates: The importance of reaction kinetics and recrystallization pathways. Sci. Total Environ. 2016, 562, 335-343. [CrossRef]

8. Wu, L.; Zhang, G.; Wang, Q.; Gu, P. Removal of strontium from liquid waste using a hydraulic pellet co-precipitation microfiltration (HPCMF) process. Desalination 2014, 349, 31-38. [CrossRef]

9. Rogers, H.; Bowers, J.; Gates-Anderson, D. An isotope dilution-precipitation process for removing radioactive cesium from wastewater. J. Hazard. Mater. 2012, 243, 124-129. [CrossRef]

10. Lauchnor, E.G.; Schultz, L.N.; Bugni, S.; Mitchell, A.C.; Cunningham, A.B.; Gerlach, R. Bacterially induced calcium carbonate precipitation and strontium coprecipitation in a porous media flow system. Environ. Sci. Technol. 2013, 47, 1557-1564. [CrossRef]

11. Sun, T.; Zheng, Z.; Chen, J.; Wang, J.; Xu, C. Efficient co-extraction of strontium and cesium from nitric acid medium by mixtures of di-tertbutylcyclohexano-18-crown-6 and 1, 3-di(2 propoxy) calix[4]arenecrown-6 in n-octanol. Sep. Sci. Technol. 2017, 53, 503-512. [CrossRef]

12. Raut, D.R.; Mohapatra, P.K. Simultaneous extraction of Cs and Sr from synthetic high level waste solutions using a solvent containing chlorinated dicarbollide and PEG-400 in PTMS. J. Radioanal. Nucl. Chem. 2014, 299, 75-80. [CrossRef]

13. Xu, C.; Wang, J.; Chen, J. Solvent extraction of strontium and cesium: A review of recent progress. Solvent Extr. Ion Exch. 2012, 30, 623-650. [CrossRef]

14. Sharma, J.N.; Kumar, A.; Kumar, V.; Pahan, S.; Janardanan, C.; Tessi, V.; Wattal, P.K. Process development for separation of cesium from acidic nuclear waste solution using 1,3-dioctyloxycalix[4]arene-crown-6 plus isodecyl alcohol/n-dodecane solvent. Sep. Purif. Technol. 2014, 135, 176-182. [CrossRef]

15. Combernoux, N.; Schrive, L.; Labed, V.; Wyart, Y.; Carretier, E.; Moulin, P. Treatment of radioactive liquid effluents by reverse osmosis membranes: From labscale to pilot-scale. Water Res. 2017, 123, 311-320. [CrossRef]

16. Dang, T.T.H.; Li, C.; Choo, K. Comparison of low-pressure reverse osmosis filtration and polyelectrolyte-enhanced ultrafiltration for the removal of Co and Sr from nuclear plant wastewater. Sep. Purif. Technol. 2016, 157, 209-214. [CrossRef]

17. Ding, S.; Yang, Y.; Li, C.; Huang, H.; Hou, L.A. The effects of organic fouling on the removal of radionuclides by reverse osmosis membranes. Water Res. 2016, 95, 174-184. [CrossRef]

18. Zhang, L.; Lu, Y.; Liu, Y.; Li, M.; Zhao, H.Y.; Hou, L.A. High flux MWCNTs-interlinked GO hybrid membranes survived in cross-flow filtration for the treatment of strontium-containing wastewater. J. Hazard. Mater. 2016, 320, 187-193. [CrossRef]

19. Yin, Y.; Wang, J.; Yang, X.; Li, W. Removal of strontium ions by immobilized saccharomyces cerevisiae in magnetic chitosan microspheres. Nucl. Eng. Technol. 2017, 49, 172-177. [CrossRef]

20. Singh, S.; Eapen, S.; Thorat, V.; Kaushik, C.P.; Raj, K.; D'souza, S.F. Phytoremediation of 137cesium and 90strontium from solutions and low-level nuclear waste by Vetiveria zizanoides. Ecotoxicol. Environ. Saf. 2008, 69, 306-311. [CrossRef]

21. Qi, X.H.; Du, K.Z.; Feng, M.L.; Li, J.R.; Du, C.F.; Zhang, B.; Huang, X.Y. A two-dimensionally microporous thiostannate with superior $\mathrm{Cs}^{+}$and $\mathrm{Sr}^{2+}$ ion-exchange property. J. Mater. Chem. A 2015, 3, 5665-5673. [CrossRef]

22. Zhang, L.; Wei, J.Y.; Zhao, X. Adsorption characteristics of strontium on synthesized antimony silicate. Chem. Eng. J. 2015, 277, 378-387. [CrossRef]

23. Villard, A.; Siboulet, B.; Toquer, G.; Merceille, A.; Grandjean, A.; Dufrêche, J.F. Strontium selectivity in sodium nonatitanate $\mathrm{Na}_{4} \mathrm{Ti}_{9} \mathrm{O}_{20} \cdot \mathrm{xH}_{2}$ O. J. Hazard. Mater. 2015, 283, 432-438. [CrossRef]

24. Naeimi, S.; Faghihian, H. Performance of novel adsorbent prepared by magnetic metal -organic framework (MOF) modified by potassium nickel hexacyanoferrate for removal of Cs+ from aqueous solution. Sep. Purif. Technol. 2017, 175, 255-265. [CrossRef]

25. Alby, D.; Charnay, C.; Heran, M.; Prelot, B.; Zajac, J. Recent developments in nanostructured inorganic materials for sorption of cesium and strontium: Synthesis and shaping, sorption capacity, mechanisms, and selectivity-A review. J. Hazard. Mater. 2018, 344, 511-530. [CrossRef]

26. Sarma, D.; Malliakas, C.D.; Subrahmanyam, K.S.; Islam, S.M.; Kanatzidis, M.G. $\mathrm{K}_{2 \mathrm{x}} \mathrm{Sn}_{4-\mathrm{x}} \mathrm{S}_{8-\mathrm{x}}(\mathrm{x}=0.65 \sim 1)$ : A new metal sulfide for rapid and selective removal of $\mathrm{Cs}^{+}, \mathrm{Sr}^{2+}$ and $\mathrm{UO}_{2}{ }^{2+}$ ions. Chem. Sci. 2016, 7, 1121-1132. [CrossRef]

27. Zhang, L.; Wei, J.; Zhao, X.; Li, F.; Jiang, F.; Zhang, M.; Cheng, X. Removal of strontium(II) and cobalt(II) from acidic solution by manganese antimonate. Chem. Eng. J. 2016, 302, 733-743. [CrossRef]

28. Sun, D.; Wang, A.; Hu, P. Research and Application prospect of geological polymers. Mater. Bull. 2009, 23, 61-65.

29. Langmuir, I. The adsorption of gases on plane surfaces of glass, mica and platinum. J. Am. Chem. Soc. 1918, 40, 1361-1403. [CrossRef]

30. Sarin, V.; Pant, K.K. Removal of chromium from industrial waste by using eucalyptus bark. Bioresour. Technol. 2006, 97, 15-20. [CrossRef]

31. Duranoğlu, D.; Trochimczuk, A.W.; Beker, U. Kinetics and thermodynamics of hexavalent chromium adsorption onto activated carbon derived from acrylonitrile-divinylbenzene copolymer. Chem. Eng. J. 2012, 187, 193-202. [CrossRef]

32. Ayawei, N.; Abasi, C.Y.; Wankasi, D.; Dikio, E.D. Layered Double Hydroxide Adsorption of Lead: Equilibrium, Thermodynamic and Kinetic Studies. Int. J. Adv. Res. Chem. Sci. 2015, 2, 22-32.

33. Ayawei, N.; Ekubo, A.T.; Wankasi, D.; Dikio, E.D. Synthesis and Application of Layered Double Hydroxide for the removal of Copper in Wastewater. Int. J. Chem. 2015, 7, 122-132.

34. Mahmoodi, N.M.; Hayati, B.; Bahrami, H.; Arami, M. Dye adsorption and desorption properties of Mentha pulegium in single and binary systems. J. Appl. Polym. Sci. 2011, 122, 1489-1499. [CrossRef] 
35. Rahmati, M.M.; Rabbani, P.; Abdolali, A.; Keshtkar, A.R. Kinetics and equilibrium studies on biosorption of cadmium, lead, and nickel ions from aqueous solutions by intact and chemically modified brown algae. J. Hazard. Mater. 2011, 185, 401-407. [CrossRef]

36. Pillai, S.S.; Mullassery, M.D.; Fernandez, N.B.; Girija, N.; Geetha, P.; Koshy, M. Biosorption of Cr(VI) from aqueous solution by chemically modified potato starch: Equilibrium and kinetic studies. Ecotoxicol. Environ. Saf. 2013, 92, 199-205. [CrossRef]

37. Suryavanshi, A.K.; Scantlebury, J.D.; Lyon, S.B. Mechanism of Friedel's salt formation in cements rich in tri-calcium aluminate. Cem. Concr. Res. 1996, 26, 717-727. [CrossRef]

38. Matschei, T.; Lothenbach, B.; Glasser, F.P. The AFm phase in Portland cement. Cem. Concr. Res. 2007, 37, 118-130. [CrossRef]

39. Zhao, X.; Liu, C.; Zuo, L.; Liu, Y.; Pang, Y. Early performance and structure of slag-modified fly ash-based geopolymer materials. J. Yangtze River Sci. Res. Inst. 2019, 36, 113.

40. Jeong, C.H. Mineralogical and hydrochemical effects on adsorption removal of cesium-137 and strontium-90 by kaolinite. J. Environ. Sci. Health A 2001, 36, 1089-1099. [CrossRef]

41. Lu, N.; Mason, C.F.V. Sorption-desorption behavior of strontium-85 onto montmorillonite and silica colloids. Appl. Geochem. 2001, 16, 1653-1662. [CrossRef]

42. Ho, Y.S. Review of second-order models for adsorption systems. J. Hazard. Mater. 2006, 136, 681-689. [CrossRef] [PubMed]

43. Eljamal, O.; Shubair, T.; Tahara, A.; Sugihara, Y.; Matsunaga, N. Iron based nanoparticles-zeolite composites for the removal of cesium from aqueous solutions. Molliq 2018, 12, 115. [CrossRef]

44. Smičiklas, I.; Dimović, S.; Plećaš, I. Removal of $\mathrm{Cs}^{+}, \mathrm{Sr}^{2+}$ and $\mathrm{Co}^{2+}$ from aqueous solutions by adsorption on natural clinoptilolite. Appl. Clay Sci. 2007, 35, 139-144. [CrossRef]

45. Lee, K.Y.; Park, M.; Kim, J.; Oh, M.; Lee, E.H.; Kim, K.W.; Moon, J.K. Equilibrium, kinetic and thermodynamic study of cesium adsorption onto nanocrystalline mordenite from high-salt solution. Chemosphere 2016, 150, 765-771. [CrossRef]

46. Vipin, A.K.; Sun, L.B.F. Removal of $\mathrm{Cs}^{+}$and $\mathrm{Sr}^{2+}$ from water using MWCNT reinforced zeolite-A beads. Microporous Mesoporous Mater. 2016, 224, 84-88. [CrossRef]

47. De Haro-Del Rio, D.A.; Al-Joubori, S.; Kontogiannis, O.; Papadatos-Gigantes, D.; Ajayi, O.; Li, C.; Holmes, S.M. The removal of caesium ions using supported clinoptilolite. J. Hazard. Mater. 2015, 289, 181. [CrossRef]

48. Borai, E.; Harjula, R.; Paajanen, A. Efficient removal of cesium from low-level radioactive liquid waste using natural and impregnated zeolite minerals. J. Hazard. Mater. 2009, 172, 416-422. [CrossRef]

49. Wang, T.-H.; Li, M.-H.; Wei, Y.-Y.; Teng, S.-P. Desorption of cesium from granite under various aqueous conditions. Appl. Radiat. Isot. 2010, 68, 2140-2146. [CrossRef]

50. Long, H.; Wu, P.; Yang, L.; Huang, Z.; Zhu, N.; Hu, Z. Efficient removal of cesium from aqueous solution with vermiculite of enhanced adsorption property through surface modification by ethylamine. J. Colloid. Interface Sci. 2014, 428, 295-301. [CrossRef]

51. Yang, S.; Han, C.; Wang, X.; Nagatsu, M. Characteristics of cesium ion sorption from aqueous solution on bentonite-and carbon nanotube-based composites. J. Hazard. Mater. 2014, 274, 46-52. [CrossRef] [PubMed]

52. Sangvanich, T.; Sukwarotwat, V.; Wiacek, R.J.; Grudzien, R.M.; Fryxell, G.E.; Addleman, R.S.; Yantasee, W. Selective capture of cesium and thallium from natural waters and simulated wastes with copper ferrocyanide functionalized mesoporous silica. J. Hazard. Mater. 2010, 182, 225-231. [CrossRef] 